\title{
Aquaporin-3 in Cancer
}

\section{Saw Marlar, Helene H. Jensen, Frédéric H. Login and Lene N. Nejsum *}

Department of Clinical Medicine, Bartholins Allé 6, Aarhus University, 8000 Aarhus C, Denmark; sawmarlar@gmail.com (S.M.); helenehalkjaer@clin.au.dk (H.H.J.); frederic.login@clin.au.dk (F.H.L.)

* Correspondence: nejsum@clin.au.dk; Tel.: +45-211-63121

Received: 8 September 2017; Accepted: 28 September 2017; Published: 7 October 2017

\begin{abstract}
Increasing evidence suggests that the water/glycerol channel aquaporin-3 (AQP3) plays a pivotal role in cancer metastasis. AQP3 knockout mice were resistant to skin tumor formation and overexpression correlated with metastasis and poor prognosis in patients with breast or gastric cancer. In cultured cancer cells, increased AQP3 expression stimulated several intracellular signaling pathways and resulted in increased cell proliferation, migration, and invasion as well as aggravation of epithelial-to-mesenchymal transition. Besides AQP facilitated water transport at the leading edge of migrating cells, AQP3 signaling mechanisms are beginning to be unraveled. Here, we give a thorough review of current knowledge regarding AQP3 expression in cancer and how AQP3 contributes to cancer progression via signaling that modulates cellular mechanisms. This review article will expand our understanding of the known pathophysiological findings regarding AQP3 in cancer.
\end{abstract}

Keywords: aquaporin-3; cancer cell migration; metastasis; AQP3

\section{Introduction}

Water accounts for approximately $50-60 \%$ of body mass, and regulation of water homeostasis is vital for all living organisms (for review [1,2]). Aquaporins (AQPs) are water channels that facilitate transepithelial water transport across plasma membranes following an osmotic gradient [3]. AQPs are glycosylated integral membrane proteins and widely expressed in bacteria (for review [4]), yeast [5], plants [6] (for review [7]), and mammals (for review [1,2,8]). Thirteen mammalian AQP isoforms have been identified (AQP0-12) (for review $[2,9]$ ) and are expressed in various tissues and organs including kidneys (for review [1,2]), eyes [10], brain [11,12] (for review [13,14]), lungs [15], skin [16,17], liver [18], sweat glands [16], and secretory glands [19] (see Figure 1A,B). AQPs are homotetramers and each monomer consists of six transmembrane domains with the $\mathrm{N}$ - and $\mathrm{C}$-termini protruding into the cytoplasm. Highly conserved Asn-Pro-Ala (NPA) motifs in loops B and E bend into the lipid bilayer forming a water-selective pore, hence each monomer contains a pore permeable to water [20,21] (see Figure $1 \mathrm{C}$ for a schematic 2D topology of AQP3). According to their permeability characteristics, AQPs are grouped into aquaporins (AQP1, AQP2, AQP4, AQP5, AQP6, and AQP8, permeable to water) and aquaglyceroporins (AQP3, AQP7, AQP9, and AQP10, permeable to water, glycerol, urea [22], and other solutes). AQP11 and AQP12 are intracellular AQPs where the physiological roles are less well characterized [23] (for review [24,25]). Besides water, some AQPs have been reported to facilitate transport of $\mathrm{H}_{2} \mathrm{O}_{2}$ (AQP3 [26,27] and AQP8 [28]), ions (AQP0 [29,30], AQP1 [31-33] and AQP6 [34]) (for review [35]), and gas (AQP1 [36-38]). 
A

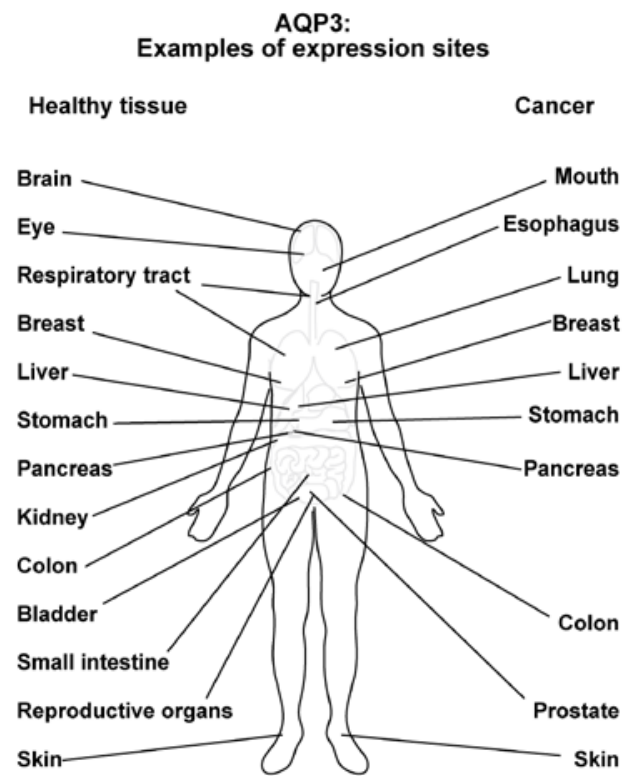

B

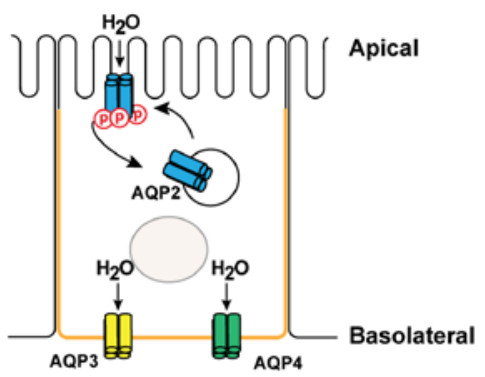

C

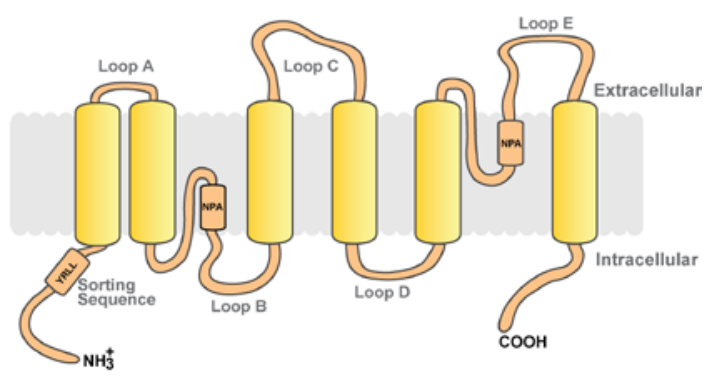

Figure 1. Aquaporin-3 expression sites, subcellular localization, and topology. (A) Schematic showing examples of aquaporin-3 (AQP3) expression sites as well as examples of cancers, where increased expression of AQP3 has been reported. (B) Schematic of a kidney collecting duct principal cell. Transepithelial water transport is facilitated by apical AQP2 allowing entry of water into the collecting duct principal cell and AQP3 and AQP4 in the basolateral plasma membrane domain (orange), which facilitate exit of water. AQP2 plasma membrane localization is regulated by phosphorylation (denoted by $\mathrm{p}$ in the schematic) mediating shuttling between intracellular vesicles and the apical plasma membrane. (C) Schematic showing the topology of AQP3. Similar to other AQPs, AQP3 has six transmembrane domains and intracellular $\mathrm{COOH}$ and $\mathrm{NH}_{3}{ }^{+}$termini. Two membrane-integrated helices with the conserved Asn-Pro-Ala (NPA) motifs generate the pore. AQP3 contains a basolateral sorting motif (YRLL) in the $\mathrm{NH}_{3}{ }^{+}$-terminal.

Although homologous, AQPs have distinct subcellular localization (Figure 1B). Polarized localization to specific plasma membrane domains enables epithelial-specific functions. For example, AQP1 is both apically and basolaterally localized in renal proximal tubule cells [39,40]. AQP3 and AQP4 are localized to basolateral membranes in renal collecting duct principal cells [41,42], however, AQP4 is predominantly basal (for review [43]). AQP2 is localized to the apical membrane and subapical vesicles in collecting duct principal cells [44] (Figure 1B). AQP5 is both apical and basolateral in the last portion of the excretory duct and exclusively apical in the first portion [16]. Moreover, AQP6 is localized to intracellular vesicles in renal collecting duct intercalated cells [45]. Short-term regulation of AQP2 levels in the apical plasma membrane of renal collecting duct principal cells occurs via shuttling of vesicles upon vasopressin stimulation, which increases intracellular cyclic adenosine monophosphate (cAMP) [46]. Moreover, short-term cAMP stimulation regulates plasma membrane diffusion of AQP2 [47,48], AQP3 [49] and AQP5 [50]. Long-term vasopressin stimulation regulates both mRNA and protein levels of AQP2 [51] and AQP3 [41]. Moreover, although destined for the same plasma membrane domain, AQP3 and AQP4 are differentially sorted in the secretory pathway [52] and also localize differently in the lateral and basal membranes [53] (for review [43]).

\section{AQP3 Expression Pattern}

AQP3 is expressed in basolateral plasma membranes of multiple human epithelia (see Figure 1A for examples of expression sites). In the gastrointestinal tract, AQP3 is expressed in gastric mucosal tissue $[17,54]$, in ileum $[17,54]$ and in distal colon $[17,54,55]$ where it contributes to water and glycerol transport in the gastrointestinal tract (for review $[56,57]$ ). In addition, AQP3 is expressed in the upper 
and lower airways [58] where it facilitates osmotic water transport across the airway epithelial cells (for review [59]). Furthermore, AQP3 is expressed in brain [54,60], breast [54], liver [61], pancreas [54,62], ovary [54], prostate [63], bladder [64], and many more epithelia [54]. In the kidney, AQP3 is expressed in the basolateral plasma membrane of collecting duct principal cells, where it is involved in fine-tuning of urine concentration [22,65-67] (see Figure 1B for schematic of a collecting duct principal cell). AQP3 is also strongly expressed in the plasma membrane of keratinocytes in the basal and spinous layers of epidermis [68,69] (for review [70]). Here, AQP3 serves as a water- and glycerol-transporter [71,72] facilitating skin hydration [73] and may also be involved in cell migration during wound healing [74]. AQP3 is also expressed in corneal epithelia where studies of AQP3 knock-out mice showed that AQP3 facilitates water and glycerol transport as well as participates in wound healing following injury [75].

\section{AQP3 in Cancer}

Recently, implication of several aquaporins in cancer has been reported (for review [76-78]) and increasing evidence strongly suggests that AQP3 plays a pivotal role in cancer progression and metastasis (for review [76-81]). A study of AQP3 knockout mice revealed that AQP3 was necessary for skin tumor development, since AQP3 knockout mice did not develop skin tumors after exposure to a tumor initiator [82]. Moreover, overexpression and ectopic expression of AQP3 has been observed in several cancers (see Figure 1A for examples of expression sites), where it contributes to metastasis, proliferation, and epithelial-to-mesenchymal transition (EMT) [83,84].

\subsection{Expression Pattern in Cancer Tissue}

AQP3 was found to be overexpressed in lung cancer [85,86], colon cancer [87], esophageal and oral squamous cell carcinoma [88]. Moreover, in hepatocellular carcinoma [89] and pancreatic ductal adenocarcinoma [90], AQP3 was dually overexpressed with AQP5. Overexpression of AQP3 was reported in 65 out of 89 patients diagnosed with gastric adenocarcinoma, and this overexpression correlated with histological classification, lymph node metastasis, and lymphovascular invasion leading to shorter patient survival compared to those with lower AQP3 expression [84]. Similarly, in a study of patients with breast invasive ductal carcinoma, increased expression of AQP3 was observed. This was associated with higher histological grade and increased spreading to lymph nodes highlighting the importance of AQP3 in breast cancer progression [83]. In a study of 94 patients with bladder carcinoma, high tumor stage was associated with decreased levels of AQP3 expression [91]. It is not known why AQP3 seems to be decreased in bladder cancer, but is overexpressed in multiple other cancers.

Together, these reports suggest AQP3 as a player in cancer. Why and how the expression of AQP3 is altered in multiple cancers is not clear. Epidermal growth factor (EGF) and estrogen both contribute to cancer development and have been suggested as upstream regulators of AQP3 expression. In cultured colorectal cancer [87], ovarian cancer [92], and pancreatic cancer cells [93], EGF treatment increased AQP3 expression. In breast cancer cells expressing estrogen receptor, stimulation with estrogen transcriptionally upregulated the levels of AQP3 [83].

It is also not clear how overexpressed or ectopically expressed AQP3 accelerates cancer progression. As discussed below, AQP3 expression affected cellular functions commonly associated with cancer progression, including proliferation, motility, and EMT. In addition, some potential downstream targets have been identified [94,95].

\subsection{Cancer Cell Proliferation}

Cancer cells are characterized by accelerated cellular proliferation. Observations from cell cultures suggest that AQP3 promotes cancer cell proliferation (for review [96]). AQP3 overexpression enhanced the proliferation of gastric cancer cells SGC7901 and MGC803 while silencing of endogenous AQP3 decreased proliferation [84]. Likewise, high expression of AQP3 increased the proliferation rate of PC12 rat pheochromocytoma cells [97] (for review [96]). Moreover, when AQP3 protein levels were decreased 
by knockdown, gastric cancer SGC7901 and MGC803 cells formed fewer spheroids, indicating that AQP3 promotes spheroid formation of these cells [98] and AQP3 knockdown in pancreatic BXPC3 and HPAFII cancer cells, decreased cell proliferation [99].

\subsection{Cancer Cell Migration}

Increased motility of cancer cells is an important aspect of cancer development. Motile cancer cells may migrate away from the primary tumor and establish metastases, which significantly complicates treatment strategies and lowers survival. Studies of other AQPs have suggested that AQP localization to the leading edge of migrating cells facilitates uptake of water, thereby causing a small swelling that facilitates forward movement by generating increased space for actin filaments [100-103] (for review [104,105]). Several studies show that AQP3 may also contribute to cancer progression by increasing the motility and invasiveness of cancer cells. Increased AQP3 expression correlated with higher histopathological grade and increased spreading to lymph nodes in patients with invasive breast ductal carcinoma [83]. In addition, AQP3 knockdown abrogated metastasis to lungs from mammary orthotopic xenographs in vivo [26], supporting the role of AQP3 in cancer metastasis. In cell cultures, AQP3 expression was associated with increased migration and invasion of T47D [83], MDA-MB-231, and DU4475 [26] breast cancer cells, while knockdown of AQP3 significantly reduced migration compared to control cells. Moreover, AQP3-facilitated transport of $\mathrm{H}_{2} \mathrm{O}_{2}$ into cells was necessary to regulate protein kinase $\mathrm{B}(\mathrm{Akt})$ phosphorylation and subsequent directional cell migration of chemokine (C-X-C motif) ligand 2 (CXCL2)-dependent breast cancer cells in vitro [26]. Together, these results suggest AQP3 as a driver of motility. Future experiments are necessary to clarify the contribution of AQP3-mediated transport of $\mathrm{H}_{2} \mathrm{O}$ and $\mathrm{H}_{2} \mathrm{O}_{2}$ in cell movement, and if AQP3 accelerates movement through stimulation of intracellular signaling pathways (Figure 2).

\subsection{Cancer Cell Invasion}

An important aspect of cancer metastasis is the ability to degrade the extracellular matrix (ECM) and invade the neighboring tissue. Matrix metalloproteases (MMPs) break down ECM proteins and facilitate migration and invasion of cancer cells. Interestingly, AQP3 overexpression positively regulated the levels of membrane type 1-matrix metalloprotease (MT1-MMP), MMP2 and MMP9, while AQP3 knockdown resulted in reduced levels in SCG7901 human gastric cancer cells [94] (Figure 2). Moreover, AQP3 silencing reduced invasiveness of DU-145 and PC-3 prostate cancer cells which was paralleled with decreased mRNA levels and hence activity of MMP3 [95]. Inhibition of extracellular signal-regulated kinase (Erk) $1 / 2$ activation also blunted these processes [95], but so far, the mechanisms connecting AQP3 to the Erk $1 / 2$ pathway remains to be characterized.

\subsection{Contribution to EMT}

Evidence implicates that overexpression of AQP3 may aggravate EMT of cancer cells. During EMT, epithelial cells convert to a more mesenchymal morphology. Cell-cell adhesions are weakened and apical-basal polarity changes to a more front-rear polarity. This is mediated by several transcriptional changes including altered expression profile of cell adhesion molecules and disruption of polarity complexes as well as cytoskeleton reorganization, which increases migration (for reviews [106-108]). Several studies of in vitro cell culture and animal tumor models have illustrated the necessary role of growth factor-induced EMT in metastasis of multiple cancers including non-small-cell lung cancer [109], breast cancer [110], liver cancer [111], colon cancer [112], head and neck squamous cell carcinoma [113], ovarian cancer [114], cervical cancer [115], bladder cancer [116], and esophageal cancer [117].

Involvement of AQP3 in increased cellular motility and invasiveness support a role in EMT. Moreover, a few studies have directly implicated AQP3 in EMT progression in cancer cells. In T47D breast cancer cells, overexpression of AQP3 caused decreased protein levels of E-cadherin, while Snail expression was increased [83]. In contrast, total protein levels of $\beta$-catenin were unchanged [83]. Similarly, in a study using the gastric cancer cell lines SGC7901 and MGC803, overexpression of 
AQP3 correlated with down-regulation of E-cadherin expression and up-regulation of vimentin and fibronectin expression [84]. In addition, T-cell factor (TCF) and lymphocyte enhancer factor (LEF), transcription factors known to be involved in EMT (for review $[106,107]$ ), were also affected by AQP3. AQP3 knockdown decreased both TCF and LEF expression levels in SGC7901 and MGC803 gastric cancer cells [98]. Thus, the mechanisms underlying regulation of EMT by AQP3 overexpression is an important future research topic to unravel the role of AQP3 in cancer.

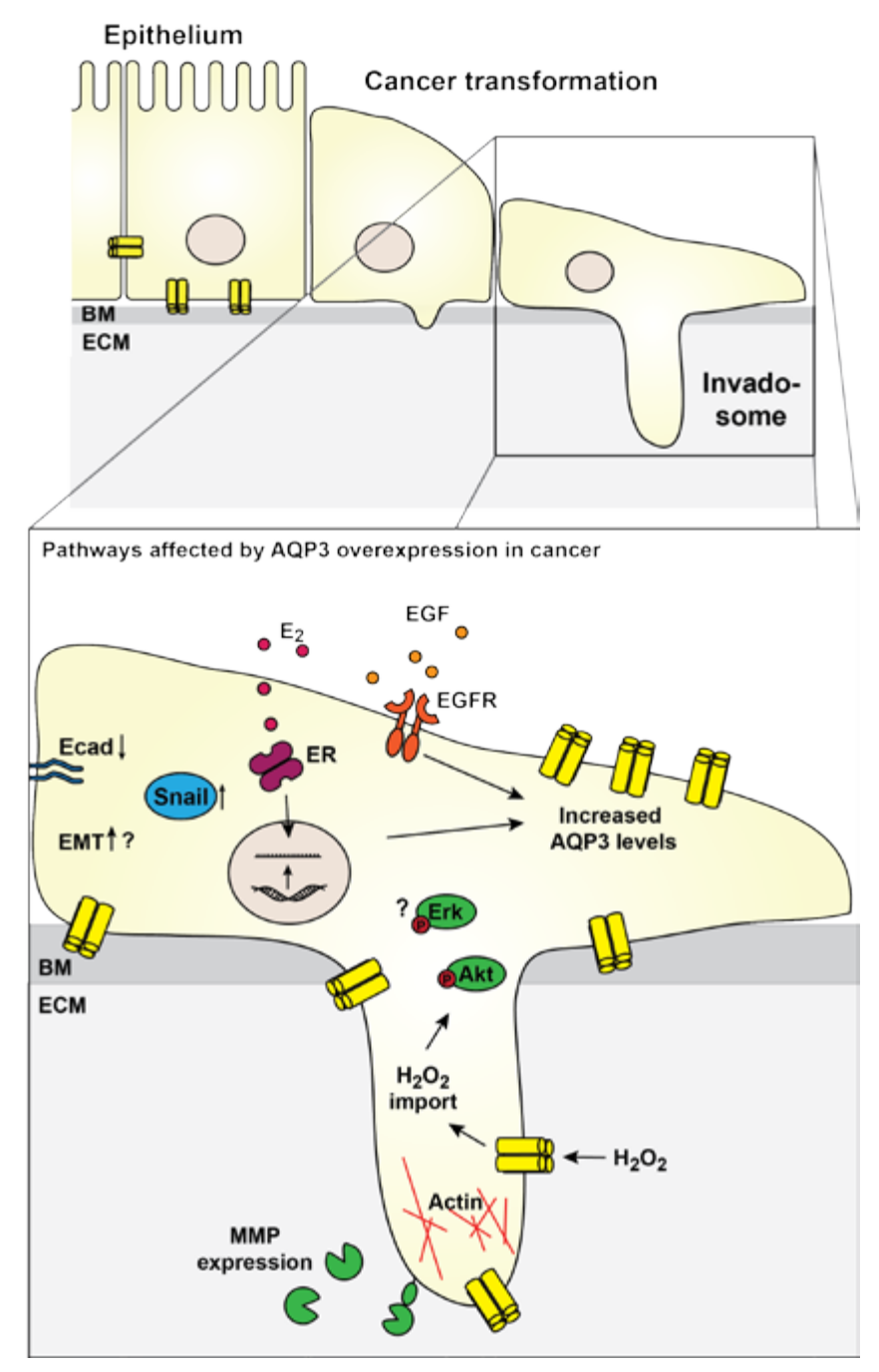

Figure 2. Schematic showing signaling affecting AQP3 overexpression and the downstream effectors. In cancer, AQP3 is often upregulated. Upregulation may be stimulated by EGF signaling. Moreover, in ER-positive breast cancer, estrogen signaling increased AQP3 transcription. Some downstream effects of AQP3 in cancer have been identified or suggested. AQP3-mediated $\mathrm{H}_{2} \mathrm{O}_{2}$ uptake was necessary for increased protein kinase B (Akt) phosphorylation, and AQP3 may also affect extracellular signal-regulated kinase (Erk)1/2 phosphorylation through so far unknown mechanisms. AQP3 overexpression was necessary for increased expression of MMPs, which promote cancer cell invasiveness. Actin is polymerized in the leading edge of migrating cells, and AQP3 localizes here as well. AQP3 overexpression facilitated downregulation of E-cadherin and up-regulation of Snail suggesting a contribution of AQP3 to EMT. BM: Basement membrane; $E_{2}$ : Estradiol; Ecad: E-cadherin; ECM: Extra-cellular matrix; EGF: Epidermal growth factor; EGFR: Epidermal growth factor receptor; EMT: Epithelial-to-mesenchymal transition; ER: Estrogen receptor; MMP: Matrix-metallo protease. 


\section{Conclusions and Perspectives}

The reports discussed here demonstrate increased AQP3 expression in many cancers, and that AQP3 overexpression contributes to cancer development. In cell culture studies, increased AQP3 expression enhances cancer-associated cellular mechanisms such as proliferation, migration and invasion, and aggravates EMT progression of cancer cells. Knock-out and knockdown experiments have shown that these effects are dependent on AQP3. Many aspects of AQP3 in cancer still need to be clarified.

Upstream AQP3 regulators have been identified. Expression of AQP3 is stimulated by hormones that are commonly increased in cancer, including EGF and estrogen. Estrogen receptor acted as a transcriptional regulator of AQP3. Similarly, during keratinocyte differentiation, the AQP3 gene has been reported as a transcriptional target of Notch signaling [118]. Future studies may further elucidate the role of upstream regulation of AQP3 in specific cancer types.

It is also important to identify if solute/water transport by AQP3 alone can explain the effect of AQP3 in cancer development, or if AQP3 can act through other mechanisms. As discussed, $\mathrm{AQP}-$ mediated solute and water transport may contribute to cancer progression. Since cancer cells have increased levels of $\mathrm{H}_{2} \mathrm{O}_{2}$ [119], AQP3-meditated $\mathrm{H}_{2} \mathrm{O}_{2}$ transport may play a role in breast cancer progression [26]. Further research is required to determine the importance of the $\mathrm{H}_{2} \mathrm{O}_{2}$ transport function of AQP3 in other cancers and the downstream signaling mechanisms. Moreover, it is of interest to identify any other potential solutes that may be transported by AQP3 and act as contributors to cancer development. Other AQPs (for reviews $[78,80,81,120]$ ) have been shown to stimulate intracellular signaling in cancer cells. AQP3 may be an upstream regulator of intracellular signaling cascades, including Akt and Erk 1/2 signaling. Unlike AQP2 or AQP5, phosphorylation or ubiquitination sites that could participate in signaling have not been identified for AQP3. It is of importance to identify if AQP3 may participate in intracellular signaling via the transport capacity or other pathways. These studies will provide further insight and advance our understanding of the molecular mechanisms behind the contribution of AQP3 to cancer metastasis. Since there are currently no efficient drugs directly targeting AQP3 expression levels, it is crucial to identify downstream signaling pathways that are stimulated by AQP3 and can be used as drug targets.

Acknowledgments: This work was supported by a Lundbeck Junior Group Leader Fellowship (R37-A3461) from the Lundbeck Foundation, a starting grant from Aarhus University Research Foundation (AUFF-E-2015-FLS-8-5-HD), and the Danish National Research Foundation, Natural Sciences (DFF-4002-00449) (all to Lene N. Nejsum).

Author Contributions: Saw Marlar wrote the first draft of the manuscript; Helene H. Jensen generated the figures; Saw Marlar, Helene H. Jensen, Frédéric H. Login and Lene N. Nejsum co-wrote the manuscript following the first draft by Saw Marlar.

Conflicts of Interest: The authors declare no conflict of interest.

\section{References}

1. Nejsum, L.N. The renal plumbing system: Aquaporin water channels. Cell. Mol. Life Sci. 2005, 62, 1692-1706. [CrossRef] [PubMed]

2. Knepper, M.A.; Kwon, T.-H.; Nielsen, S. Molecular physiology of water balance. N. Engl. J. Med. 2015, 372, 1349-1358. [CrossRef] [PubMed]

3. Preston, G.M.; Carroll, T.P.; Guggino, W.B.; Agre, P. Appearance of water channels in Xenopus oocytes expressing red cell CHIP28 protein. Science 1992, 256, 385-387. [CrossRef] [PubMed]

4. Hohmann, S.; Bill, R.M.; Kayingo, G.; Prior, B.A. Microbial MIP channels. Trends Microbiol. 2000, 8, $33-38$. [CrossRef]

5. Bonhivers, M.; Carbrey, J.M.; Gould, S.J.; Agre, P. Aquaporins in Saccharomyces: Genetic and functional distinctions between laboratory and wild-type strains. J. Biol. Chem. 1998, 273, 27565-27572. [CrossRef] [PubMed] 
6. Maurel, C.; Reizer, J.; Schroeder, J.I.; Chrispeels, M.J. The vacuolar membrane protein $\gamma$-TIP creates water specific channels in Xenopus oocytes. EMBO J. 1993, 12, 2241-2247. [PubMed]

7. Maurel, C.; Boursiac, Y.; Luu, D.-T.; Santoni, V.; Shahzad, Z.; Verdoucq, L. Aquaporins in plants. Physiol. Rev. 2015, 95, 1321-1358. [CrossRef] [PubMed]

8. King, L.S.; Kozono, D.; Agre, P. From structure to disease: The evolving tale of aquaporin biology. Nat. Rev. Mol. Cell Biol. 2004, 5, 687-698. [CrossRef] [PubMed]

9. Day, R.E.; Kitchen, P.; Owen, D.S.; Bland, C.; Marshall, L.; Conner, A.C.; Bill, R.M.; Conner, M.T. Human aquaporins: Regulators of transcellular water flow. Biochim. Biophys. Acta Gen. Subj. 2014, 1840, 1492-1506. [CrossRef] [PubMed]

10. Hamann, S.; Zeuthen, T.; La Cour, M.; Nagelhus, E.A.; Ottersen, O.P.; Agre, P.; Nielsen, S. Aquaporins in complex tissues: Distribution of aquaporins 1-5 in human and rat eye. Am. J. Physiol. 1998, 274, C1332-C1345. [PubMed]

11. Hasegawa, H.; Ma, T.; Skach, W.; Matthay, M.A.; Verkman, A.S. Molecular cloning of a mercurial-insensitive water channel expressed in selected water-transporting tissues. J. Biol. Chem. 1994, 269, 5497-5500. [PubMed]

12. Frigeri, A.; Gropper, M.A.; Turck, C.W.; Verkman, A.S. Immunolocalization of the mercurial-insensitive water channel and glycerol intrinsic protein in epithelial cell plasma membranes. Proc. Natl. Acad. Sci. USA 1995, 92, 4328-4331. [CrossRef] [PubMed]

13. Filippidis, A.S.; Carozza, R.B.; Rekate, H.L. Aquaporins in brain edema and neuropathological conditions. Int. J. Mol. Sci. 2017, 18, 55. [CrossRef] [PubMed]

14. Nagelhus, E.A.; Ottersen, O.P. Physiological roles of aquaporin-4 in brain. Physiol. Rev. 2013, 93, $1543-1562$. [CrossRef] [PubMed]

15. Nielsen, S.; King, L.S.; Christensen, B.M.; Agre, P. Aquaporins in complex tissues. II. Subcellular distribution in respiratory and glandular tissues of rat. Am. J. Physiol. 1997, 273, C1549-C1561. [PubMed]

16. Nejsum, L.N.; Kwon, T.-H.; Jensen, U.B.; Fumagalli, O.; Frokiaer, J.; Krane, C.M.; Menon, A.G.; King, L.S.; Agre, P.C.; Nielsen, S. Functional requirement of aquaporin-5 in plasma membranes of sweat glands. Proc. Natl. Acad. Sci. USA 2002, 99, 511-516. [CrossRef] [PubMed]

17. Matsuzaki, T.; Suzuki, T.; Koyama, H.; Tanaka, S.; Takata, K. Water channel protein AQP3 is present in epithelia exposed to the environment of possible water loss. J. Histochem. Cytochem. 1999, 47, 1275-1286. [CrossRef] [PubMed]

18. Elkjaer, M.; Vajda, Z.; Nejsum, L.N.; Kwon, T.; Jensen, U.B.; Amiry-Moghaddam, M.; Frøkiaer, J.; Nielsen, S. Immunolocalization of AQP9 in liver, epididymis, testis, spleen, and brain. Biochem. Biophys. Res. Commun. 2000, 276, 1118-1128. [CrossRef] [PubMed]

19. Gresz, V.; Kwon, T.-H.; Hurley, P.T.; Varga, G.; Zelles, T.; Nielsen, S.; Case, R.M.; Steward, M.C. Identification and localization of aquaporin water channels in human salivary glands. Am. J. Physiol. Gastrointest. Liver Physiol. 2001, 281, G247-G254. [PubMed]

20. Jung, J.S.; Prestont, G.M.; Smith, B.L.; Guggino, W.B.; Agre, P. Molecular structure of the water channel through aquaporin CHIP: The hourglass model. J. Biol. Chem. 1994, 269, 14648-14654. [PubMed]

21. Preston, G.M.; Agre, P. Isolation of the cDNA for erythrocyte integral membrane protein of 28 kilodaltons: Member of an ancient channel family. Proc. Natl. Acad. Sci. USA 1991, 88, 11110-11114. [CrossRef] [PubMed]

22. Ishibashi, K.; Sasaki, S.; Fushimi, K.; Uchida, S.; Kuwahara, M.; Saito, H.; Furukawa, T.; Nakajima, K.; Yamaguchi, Y.; Gojobori, T. Molecular cloning and expression of a member of the aquaporin family with permeability to glycerol and urea in addition to water expressed at the basolateral membrane of kidney collecting duct cells. Proc. Natl. Acad. Sci. USA 1994, 91, 6269-6273. [CrossRef] [PubMed]

23. Rützler, M.; Rojek, A.; Damgaard, M.V.; Andreasen, A.; Fenton, R.A.; Nielsen, S. Temporal deletion of Aqp11 in mice is linked to the severity of cyst-like disease. Am. J. Physiol. Renal Physiol. 2017, 312, F343-F351. [CrossRef] [PubMed]

24. Rojek, A.; Praetorius, J.; Frokiaer, J.; Nielsen, S.; Fenton, R.A. A current view of the mammalian aquaglyceroporins. Annu. Rev. Physiol. 2008, 70, 301-327. [CrossRef] [PubMed]

25. Ishibashi, K. Aquaporin superfamily with unusual NPA boxes: S-aquaporins (superfamily, sip-like and subcellular-aquaporins). Cell. Mol. Biol. 2006, 52, 20-27. [PubMed]

26. Satooka, H.; Hara-Chikuma, M. Aquaporin-3 controls breast cancer cell migration by regulating hydrogen peroxide transport and its downstream cell signaling. Mol. Cell. Biol. 2016, 36, 1206-1218. [CrossRef] [PubMed] 
27. Hara-Chikuma, M.; Satooka, H.; Watanabe, S.; Honda, T.; Miyachi, Y.; Watanabe, T.; Verkman, A.S. Aquaporin-3-mediated hydrogen peroxide transport is required for NF- $\mathrm{kB}$ signalling in keratinocytes and development of psoriasis. Nat. Commun. 2015, 6, 7454. [CrossRef] [PubMed]

28. Almasalmeh, A.; Krenc, D.; Wu, B.; Beitz, E. Structural determinants of the hydrogen peroxide permeability of aquaporins. FEBS J. 2014, 281, 647-656. [CrossRef] [PubMed]

29. Zampighi, G.A.; Hall, J.E.; Kreman, M. Purified lens junctional protein forms channels in planar lipid films. Proc. Natl. Acad. Sci. USA 1985, 82, 8468-8472. [CrossRef] [PubMed]

30. Shen, L.; Shrager, P.; Girsch, S.J.; Donaldson, P.J.; Peracchia, C. Channel reconstitution in liposomes and planar bilayers with HPLC-purified MIP26 of bovine lens. J. Membr. Biol. 1991, 124, 21-32. [CrossRef] [PubMed]

31. Saparov, S.M.; Kozono, D.; Rothe, U.; Agre, P.; Pohl, P. Water and ion permeation of aquaporin-1 in planar lipid bilayers. Major differences in structural determinants and stoichiometry. J. Biol. Chem. 2001, 276, 31515-31520. [CrossRef] [PubMed]

32. Anthony, T.L.; Brooks, H.L.; Boassa, D.; Leonov, S.; Yanochko, G.M.; Regan, J.W.; Yool, A.J. Cloned human aquaporin-1 is a cyclic GMP-gated ion channel. Mol. Pharmacol. 2000, 57, 576-588. [CrossRef] [PubMed]

33. Yool, A.J.; Stamer, W.D.; Regan, J.W. Forskolin stimulation of water and cation permeability in aquaporin 1 water channels. Science 1996, 273, 1216-1218. [CrossRef] [PubMed]

34. Yasui, M.; Hazama, A.; Kwon, T.H.; Nielsen, S.; Guggino, W.B.; Agre, P. Rapid gating and anion permeability of an intracellular aquaporin. Nature 1999, 402, 184-187. [CrossRef] [PubMed]

35. Yool, A.J.; Campbell, E.M. Structure, function and translational relevance of aquaporin dual water and ion channels. Mol. Asp. Med. 2012, 33, 553-561. [CrossRef] [PubMed]

36. Endeward, V. Evidence that aquaporin 1 is a major pathway for $\mathrm{CO}_{2}$ transport across the human erythrocyte membrane. FASEB J. 2006, 20, 1974-1981. [CrossRef] [PubMed]

37. Nakhoul, N.L.; Davis, B.A.; Romero, M.F.; Boron, W.F. Effect of expressing the water channel aquaporin-1 on the $\mathrm{CO}_{2}$ permeability of Xenopus oocytes. Am. J. Physiol. 1998, 274, C543-C548. [CrossRef] [PubMed]

38. Yang, B.; Fukuda, N.; van Hoek, A.; Matthay, M.A.; Ma, T.; Verkman, A.S. Carbon dioxide permeability of aquaporin-1 measured in erythrocytes and lung of aquaporin-1 null mice and in reconstituted proteoliposomes. J. Biol. Chem. 2000, 275, 2686-2692. [CrossRef] [PubMed]

39. Nielsen, S.; Smith, B.L.; Christensen, E.I.; Knepper, M.A.; Agre, P. CHIP28 water channels are localized in constitutively water-permeable segments of the nephron. J. Cell Biol. 1993, 120, 371-383. [CrossRef] [PubMed]

40. Sabolić, I.; Valenti, G.; Verbavatz, J.M.; van Hoek, A.N.; Verkman, A.S.; Ausiello, D.A.; Brown, D. Localization of the CHIP28 water channel in rat kidney. Am. J. Physiol. 1992, 263, C1225-C1233. [PubMed]

41. Ecelbarger, C.A.; Terris, J.; Frindt, G.; Echevarria, M.; Marples, D.; Nielsen, S.; Knepper, M.A. Aquaporin-3 water channel localization and regulation in rat kidney. Am. J. Physiol. 1995, 269, F663-F672. [PubMed]

42. Terris, J.; Ecelbarger, C.A.; Marples, D.; Knepper, M.A.; Nielsen, S. Distribution of aquaporin-4 water channel expression within rat kidney. Am. J. Physiol. 1995, 269, F775-F785. [PubMed]

43. Marples, D.; Frøkiaer, J.; Nielsen, S. Long-term regulation of aquaporins in the kidney. Am. J. Physiol. 1999, 276, F331-F339. [PubMed]

44. Nielsen, S.; DiGiovanni, S.R.; Christensen, E.I.; Knepper, M.A.; Harris, H.W. Cellular and subcellular immunolocalization of vasopressin-regulated water channel in rat kidney. Proc. Natl. Acad. Sci. USA 1993, 90, 11663-11667. [CrossRef] [PubMed]

45. Yasui, M.; Kwon, T.-H.; Knepper, M.A.; Nielsen, S.; Agre, P. Aquaporin-6: An intracellular vesicle water channel protein in renal epithelia. Proc. Natl. Acad. Sci. USA 1999, 96, 5808-5813. [CrossRef] [PubMed]

46. Nielsen, S.; Chou, C.L.; Marples, D.; Christensen, E.I.; Kishore, B.K.; Knepper, M.A. Vasopressin increases water permeability of kidney collecting duct by inducing translocation of aquaporin-CD water channels to plasma membrane. Proc. Natl. Acad. Sci. USA 1995, 92, 1013-1017. [CrossRef] [PubMed]

47. Umenishi, F.; Verbavatz, J.M.; Verkman, A.S. cAMP regulated membrane diffusion of a green fluorescent protein-aquaporin 2 chimera. Biophys. J. 2000, 78, 1024-1035. [CrossRef]

48. Arnspang, E.C.; Login, F.H.; Koffman, J.S.; Sengupta, P.; Nejsum, N.L. AQP2 plasma membrane diffusion is altered by the degree of AQP2-S256 phosphorylation. Int J Mol Sci. 2016, 17, 1804. [CrossRef] [PubMed] 
49. Marlar, S.; Arnspang, E.C.; Koffman, J.S.; Locke, E.M.; Christensen, B.M.; Nejsum, L.N. Elevated cAMP increases aquaporin-3 plasma membrane diffusion. Am. J. Physiol. Cell Physiol. 2014, 306, C598-C606. [CrossRef] [PubMed]

50. Koffman, J.S.; Arnspang, E.C.; Marlar, S.; Nejsum, L.N. Opposing effects of cAMP and T259 phosphorylation on plasma membrane diffusion of the water channel aquaporin-5 in Madin-Darby canine kidney cells. PLoS ONE 2015, 10, e0133324. [CrossRef] [PubMed]

51. DiGiovanni, S.R.; Nielsen, S.; Christensen, E.I.; Knepper, M.A. Regulation of collecting duct water channel expression by vasopressin in Brattleboro rat. Proc. Natl. Acad. Sci. USA 1994, 91, 8984-8988. [CrossRef] [PubMed]

52. Arnspang, E.C.; Sundbye, S.; Nelson, W.J.; Nejsum, L.N. Aquaporin-3 and aquaporin-4 are sorted differently and separately in the trans-Golgi network. PLoS ONE 2013, 8, e73977. [CrossRef] [PubMed]

53. Marlar, S.; Arnspang, E.C.; Pedersen, G.A.; Koffman, J.S.; Nejsum, L.N. Measuring localization and diffusion coefficients of basolateral proteins in lateral versus basal membranes using functionalized substrates and kICS analysis. Biochim. Biophys. Acta Biomembr. 2014, 1838, 2404-2411. [CrossRef] [PubMed]

54. Mobasheri, A.; Wray, S.; Marples, D. Distribution of AQP2 and AQP3 water channels in human tissue microarrays. J. Mol. Histol. 2005, 36, 1-14. [CrossRef] [PubMed]

55. Silberstein, C.; Kierbel, A.; Amodeo, G.; Zotta, E.; Bigi, F.; Berkowski, D.; Ibarra, C. Functional characterization and localization of AQP3 in the human colon. Brazilian J. Med. Biol. Res. 1999, 32, 1303-1313. [CrossRef]

56. Ma, T.; Verkman, A.S. Aquaporin water channels in gastrointestinal physiology. J. Physiol. 1999, 517, $317-326$. [CrossRef] [PubMed]

57. Zhu, C.; Chen, Z.; Jiang, Z. Expression, distribution and role of aquaporin water channels in human and animal stomach and intestines. Int. J. Mol. Sci. 2016, 17, 1399. [CrossRef] [PubMed]

58. Kreda, S.M.; Gynn, M.C.; Fenstermacher, D.A.; Boucher, R.C.; Gabriel, S.E. Expression and localization of epithelial aquaporins in the adult human lung. Am. J. Respir. Cell Mol. Biol. 2001, 24, 224-234. [CrossRef] [PubMed]

59. Verkman, A.S. Role of aquaporins in lung liquid physiology. Respir. Physiol. Neurobiol. 2007, 159, $324-330$. [CrossRef] [PubMed]

60. Yamamoto, N.; Yoneda, K.; Asai, K.; Sobue, K.; Tada, T.; Fujita, Y.; Katsuya, H.; Fujita, M.; Aihara, N.; Mase, M.; et al. Alterations in the expression of the AQP family in cultured rat astrocytes during hypoxia and reoxygenation. Mol. Brain Res. 2001, 90, 26-38. [CrossRef]

61. Gregoire, F.; Lucidi, V.; Zerrad-Saadi, A.; Virreira, M.; Bolaky, N.; Delforge, V.; Lemmers, A.; Donckier, V.; Devière, J.; Demetter, P.; et al. Analysis of aquaporin expression in liver with a focus on hepatocytes. Histochem. Cell Biol. 2015, 144, 347-363. [CrossRef] [PubMed]

62. Ishibashi, K.; Sasaki, S.; Saito, F.; Ikeuchi, T.; Marumo, F. Structure and chromosomal localization of a human water channel (AQP3) gene. Genomics 1995, 27, 352-354. [CrossRef] [PubMed]

63. Wang, J.; Tanji, N.; Kikugawa, T.; Shudou, M.; Song, X.; Yokoyama, M. Expression of aquaporin 3 in the human prostate. Int. J. Urol. 2007, 14, 1088-1092. [CrossRef] [PubMed]

64. Rubenwolf, P.C.; Georgopoulos, N.T.; Clements, L.A.; Feather, S.; Holland, P.; Thomas, D.F.M.; Southgate, J. Expression and localisation of aquaporin water channels in human urothelium in situ and in vitro. Eur. Urol. 2009, 56, 1013-1024. [CrossRef] [PubMed]

65. Yang, B.; Ma, T.; Verkman, A.S. Erythrocyte water permeability and renal function in double knock out mice lacking aquaporin-1 and aquaporin-3. J. Biol. Chem. 2001, 276, 624-628. [CrossRef] [PubMed]

66. Ma, T.; Song, Y.; Yang, B.; Gillespie, A.; Carlson, E.J.; Epstein, C.J.; Verkman, A.S. Nephrogenic diabetes insipidus in mice lacking aquaporin-3 water channels. Proc. Natl. Acad. Sci. USA 2000, 97, 4386-4391. [CrossRef] [PubMed]

67. Echevarria, M.; Windhager, E.E.; Tate, S.S.; Frindt, G. Cloning and expression of AQP3, a water channel from the medullary collecting duct of rat kidney. Proc. Natl. Acad. Sci. USA 1994, 91, 10997-11001. [CrossRef] [PubMed]

68. Sougrat, R.; Morand, M.; Gondran, C.; Barré, P.; Gobin, R.; Bonté, F.; Dumas, M.; Verbavatz, J.-M. Functional expression of AQP3 in human skin epidermis and reconstructed epidermis. J. Invest. Dermatol. 2002, 118, 678-685. [CrossRef] [PubMed] 
69. Frigeri, A.; Gropper, M.A.; Umenishi, F.; Kawashima, M.; Brown, D.; Verkman, A.S. Localization of MIWC and GLIP water channel homologs in neuromuscular, epithelial and glandular tissues. J. Cell Sci. 1995, 108, 2993-3002. [PubMed]

70. Blaydon, D.C.; Kelsell, D.P. Defective channels lead to an impaired skin barrier. J. Cell Sci. 2014, 127, 4343-4350. [CrossRef] [PubMed]

71. Boury-Jamot, M.; Sougrat, R.; Tailhardat, M.; le Varlet, B.; Bonté, F.; Dumas, M.; Verbavatz, J.M. Expression and function of aquaporins in human skin: Is aquaporin-3 just a glycerol transporter? Biochim. Biophys. Acta Biomembr. 2006, 1758, 1034-1042. [CrossRef] [PubMed]

72. Hara, M.; Verkman, A.S. Glycerol replacement corrects defective skin hydration, elasticity, and barrier function in aquaporin-3-deficient mice. Proc. Natl. Acad. Sci. USA 2003, 100, 7360-7365. [CrossRef] [PubMed]

73. Tonghui, M.; Hara, M.; Sougrat, R.; Verbavatz, J.M.; Verkman, A.S. Impaired stratum corneum hydration in mice lacking epidermal water channel aquaporin-3. J. Biol. Chem. 2002, 277, 17147-17153. [CrossRef]

74. Hara-Chikuma, M.; Verkman, A.S. Aquaporin-3 facilitates epidermal cell migration and proliferation during wound healing. J. Mol. Med. 2008, 86, 221-231. [CrossRef] [PubMed]

75. Levin, M.H.; Verkman, A.S. Aquaporin-3-dependent cell migration and proliferation during corneal re-epithelialization. Investig. Ophthalmol. Vis. Sci. 2006, 47, 4365-4372. [CrossRef] [PubMed]

76. Verkman, A.S. Aquaporins in clinical medicine. Annu. Rev. Med. 2012, 63, 303-316. [CrossRef] [PubMed]

77. Ribatti, D.; Ranieri, G.; Annese, T.; Nico, B. Aquaporins in cancer. Biochim. Biophys. Acta Gen. Subj. 2014, 1840, 1550-1553. [CrossRef] [PubMed]

78. Wang, J.; Feng, L.; Zhu, Z.; Zheng, M.; Wang, D.; Chen, Z.; Sun, H. Aquaporins as diagnostic and therapeutic targets in cancer: How far we are? J. Transl. Med. 2015, 13, 96. [CrossRef] [PubMed]

79. Papadopoulos, M.C.; Saadoun, S. Key roles of aquaporins in tumor biology. Biochim. Biophys. Acta Biomembr. 2015, 1848, 2576-2583. [CrossRef] [PubMed]

80. Jensen, H.H.; Login, F.H.; Koffman, J.S.; Kwon, T.-H.; Nejsum, L.N. The role of aquaporin-5 in cancer cell migration: A potential active participant. Int. J. Biochem. Cell Biol. 2016, 79, 271-276. [CrossRef] [PubMed]

81. Verkman, A.S.; Hara-Chikuma, M.; Papadopoulos, M.C. Aquaporins-New players in cancer biology. J. Mol. Med. 2008, 86, 523-529. [CrossRef] [PubMed]

82. Hara-Chikuma, M.; Verkman, A.S. Prevention of skin tumorigenesis and impairment of epidermal cell proliferation by targeted aquaporin-3 gene disruption. Mol. Cell. Biol. 2008, 28, 326-332. [CrossRef] [PubMed]

83. Huang, Y.-T.; Zhou, J.; Shi, S.; Xu, H.-Y.; Qu, F.; Zhang, D.; Chen, Y.-D.; Yang, J.; Huang, H.-F.; Sheng, J.-Z. Identification of estrogen response element in aquaporin-3 gene that mediates estrogen-induced cell migration and invasion in estrogen receptor-positive breast cancer. Sci. Rep. 2015, 5, 12484. [CrossRef] [PubMed]

84. Chen, J.; Wang, T.; Zhou, Y.-C.; Gao, F.; Zhang, Z.-H.; Xu, H.; Wang, S.-L.; Shen, L.-Z. Aquaporin 3 promotes epithelial-mesenchymal transition in gastric cancer. J. Exp. Clin. Cancer Res. 2014, 33, 38. [CrossRef] [PubMed]

85. Liu, Y.L.; Matsuzaki, T.; Nakazawa, T.; Murata, S.; Nakamura, N.; Kondo, T.; Iwashina, M.; Mochizuki, K.; Yamane, T.; Takata, K.; et al. Expression of aquaporin 3 (AQP3) in normal and neoplastic lung tissues. Hum. Pathol. 2007, 38, 171-178. [CrossRef] [PubMed]

86. Machida, Y.; Ueda, Y.; Shimasaki, M.; Sato, K.; Sagawa, M.; Katsuda, S.; Sakuma, T. Relationship of aquaporin 1,3 , and 5 expression in lung cancer cells to cellular differentiation, invasive growth, and metastasis potential. Hum. Pathol. 2011, 42, 669-678. [CrossRef] [PubMed]

87. Li, A.; Lu, D.; Zhang, Y.; Li, J.; Fang, Y.; Li, F.; Sun, J. Critical role of aquaporin-3 in epidermal growth factor-induced migration of colorectal carcinoma cells and its clinical significance. Oncol. Rep. 2013, 29, 535-540. [CrossRef] [PubMed]

88. Kusayama, M.; Wada, K.; Nagata, M.; Ishimoto, S.; Takahashi, H.; Yoneda, M.; Nakajima, A.; Okura, M.; Kogo, M.; Kamisaki, Y. Critical role of aquaporin 3 on growth of human esophageal and oral squamous cell carcinoma. Cancer Sci. 2011, 102, 1128-1136. [CrossRef] [PubMed]

89. Guo, X.; Sun, T.; Yang, M.; Li, Z.; Li, Z.; Gao, Y. Prognostic value of combined aquaporin 3 and aquaporin 5 overexpression in hepatocellular carcinoma. Biomed Res. Int. 2013, 2013, 206525. [CrossRef] [PubMed]

90. Direito, I.; Paulino, J.; Vigia, E.; Brito, M.A.; Soveral, G. Differential expression of aquaporin-3 and aquaporin-5 in pancreatic ductal adenocarcinoma. J. Surg. Oncol. 2017, 115, 1-17. [CrossRef] [PubMed] 
91. Rubenwolf, P.C.; Otto, W.; Denzinger, S.; Hofstädter, F.; Wieland, W.; Georgopoulos, N.T. Expression of aquaporin water channels in human urothelial carcinoma: Correlation of AQP3 expression with tumour grade and stage. World J. Urol. 2014, 32, 991-997. [CrossRef] [PubMed]

92. Ji, C.; Cao, C.; Lu, S.; Kivlin, R.; Amaral, A.; Kouttab, N.; Yang, H.; Chu, W.; Bi, Z.; Di, W.; et al. Curcumin attenuates EGF-induced AQP3 up-regulation and cell migration in human ovarian cancer cells. Cancer Chemother. Pharmacol. 2008, 62, 857-865. [CrossRef] [PubMed]

93. Liu, W.; Wang, K.; Gong, K.; Li, X.; Luo, K. Epidermal growth factor enhances MPC-83 pancreatic cancer cell migration through the upregulation of aquaporin 3. Mol. Med. Rep. 2012, 6, 607-610. [CrossRef] [PubMed]

94. Xu, H.; Xu, Y.; Zhang, W.; Shen, L.; Yang, L.; Xu, Z. Aquaporin-3 positively regulates matrix metalloproteinases via PI3K/AKT signal pathway in human gastric carcinoma SGC7901 cells. J. Exp. Clin. Cancer Res. 2011, 30, 86. [CrossRef] [PubMed]

95. Chen, J.; Wang, Z.; Xu, D.; Liu, Y.; Gao, Y. Aquaporin 3 promotes prostate cancer cell motility and invasion via extracellular signal-regulated kinase 1/2-mediated matrix metalloproteinase-3 secretion. Mol. Med. Rep. 2015, 11, 2882-2888. [CrossRef] [PubMed]

96. Galán-Cobo, A.; Ramírez-Lorca, R.; Echevarría, M. Role of aquaporins in cell proliferation: What else beyond water permeability? Channels 2016, 10, 185-201. [CrossRef] [PubMed]

97. Galán-Cobo, A.; Ramírez-Lorca, R.; Serna, A.; Echevarría, M. Overexpression of AQP3 modifies the cell cycle and the proliferation rate of mammalian cells in culture. PLoS ONE 2015, 10. [CrossRef] [PubMed]

98. Zhou, Y.; Wang, Y.; Wen, J.; Zhao, H.; Dong, X.; Zhang, Z.; Wang, S.; Shen, L. Aquaporin 3 promotes the stem-like properties of gastric cancer cells via Wnt/GSK-3 $\beta / \beta$-catenin pathway. Oncotarget 2016, 7, 16529-16541. [CrossRef] [PubMed]

99. Huang, X.; Huang, L.; Shao, M. Aquaporin 3 facilitates tumor growth in pancreatic cancer by modulating mTOR signaling. Biochem. Biophys. Res. Commun. 2017, 486, 1097-1102. [CrossRef] [PubMed]

100. Stroka, K.M.; Jiang, H.; Chen, S.H.; Tong, Z.; Wirtz, D.; Sun, S.X.; Konstantopoulos, K. Water permeation drives tumor cell migration in confined microenvironments. Cell 2014, 157, 611-623. [CrossRef] [PubMed]

101. Oster, G.F.; Perelson, A.S. The physics of cell motility. J. Cell Sci. 1987, 8, 35-54. [CrossRef]

102. Karlsson, T.; Bolshakova, A.; Magalhães, M.A.O.; Loitto, V.M.; Magnusson, K.E. Fluxes of water through aquaporin 9 weaken membrane-cytoskeleton anchorage and promote formation of membrane protrusions. PLoS ONE 2013, 8, 1-14. [CrossRef] [PubMed]

103. Jaeger, M.; Carin, M.; Medale, M.; Tryggvason, G. The osmotic migration of cells in a solute gradient. Biophys. J. 1999, 77, 1257-1267. [CrossRef]

104. Papadopoulos, M.C.; Saadoun, S.; Verkman, A.S. Aquaporins and cell migration. Pflugers Arch. 2008, 456, 693-700. [CrossRef] [PubMed]

105. Loitto, V.M.; Karlsson, T.; Magnusson, K.E. Water flux in cell motility: Expanding the mechanisms of membrane protrusion. Cell Motil. Cytoskeleton 2009, 66, 237-247. [CrossRef] [PubMed]

106. Lamouille, S.; Xu, J.; Derynck, R. Molecular mechanisms of epithelial-mesenchymal transition. Nat. Rev. Mol. Cell Biol. 2014, 15, 178-196. [CrossRef] [PubMed]

107. Gonzalez, D.M.; Medici, D. Signaling mechanisms of the epithelial-mesenchymal transition. Sci. Signal. 2014, 7, 16529-16541. [CrossRef] [PubMed]

108. Thiery, J.P.; Acloque, H.; Huang, R.Y.J.; Nieto, M.A. Epithelial-mesenchymal transitions in development and disease. Cell 2009, 139, 871-890. [CrossRef] [PubMed]

109. Liu, F.; Song, S.; Yi, Z.; Zhang, M.; Li, J.; Yang, F.; Yin, H.; Yu, X.; Guan, C.; Liu, Y.; et al. HGF induces EMT in non-small-cell lung cancer through the hBVR pathway. Eur. J. Pharmacol. 2016, 811, 180-190. [CrossRef] [PubMed]

110. Davis, F.M.; Azimi, I.; Faville, R.A.; Peters, A.A.; Jalink, K.; Putney, J.W.; Goodhill, G.J.; Thompson, E.W.; Roberts-Thomson, S.J.; Monteith, G.R. Induction of epithelial-mesenchymal transition (EMT) in breast cancer cells is calcium signal dependent. Oncogene 2014, 33, 2307-2316. [CrossRef] [PubMed]

111. Ogunwobi, O.O.; Wang, T.; Zhang, L.; Liu, C. COX-2 and Akt mediate multiple growth factor-induced epithelial-mesenchymal transition in human hepatocellular carcinoma. J. Gastroenterol. Hepatol. 2012, 27, 566-578. [CrossRef] [PubMed]

112. Pino, M.S.; Kikuchi, H.; Zeng, M.; Herraiz, M.-T.; Sperduti, I.; Berger, D.; Park, D.-Y.; Iafrate, A.J.; Zukerberg, L.R.; Chung, D.C. Epithelial to mesenchymal transition is impaired in colon cancer cells with microsatellite instability. Gastroenterology 2010, 138, 1406-1417. [CrossRef] [PubMed] 
113. Zuo, J.H.; Zhu, W.; Li, M.Y.; Li, X.H.; Yi, H.; Zeng, G.Q.; Wan, X.X.; He, Q.Y.; Li, J.H.; Qu, J.Q.; et al. Activation of EGFR promotes squamous carcinoma SCC10A cell migration and invasion via inducing EMT-like phenotype change and MMP-9-mediated degradation of E-cadherin. J. Cell. Biochem. 2011, 112, 2508-2517. [CrossRef] [PubMed]

114. Yue, P.; Zhang, X.; Paladino, D.; Sengupta, B.; Ahmad, S.; Holloway, R.W.; Ingersoll, S.B.; Turkson, J. Hyperactive EGF receptor, Jaks and Stat3 signaling promote enhanced colony-forming ability, motility and migration of cisplatin-resistant ovarian cancer cells. Oncogene 2012, 31, 2309-2322. [CrossRef] [PubMed]

115. Lee, M.-Y.; Chou, C.-Y.; Tang, M.-J.; Shen, M.-R. Epithelial-mesenchymal transition in cervical cancer: correlation with tumor progression, epidermal growth factor receptor overexpression, and snail up-regulation. Clin. Cancer Res. 2008, 14, 4743-4750. [CrossRef] [PubMed]

116. Liu, J.; Cao, J.; Zhao, X. miR-221 facilitates the TGF $\beta 1$-induced epithelial-mesenchymal transition in human bladder cancer cells by targeting STMN1. BMC Urol. 2015, 15, 36. [CrossRef] [PubMed]

117. Li, J.; Shan, F.; Xiong, G.; Chen, X.; Guan, X.; Wang, J.-M.; Wang, W.-L.; Xu, X.; Bai, Y. EGF-induced C/EBP $\beta$ participates in EMT by decreasing the expression of miR-203 in esophageal squamous cell carcinoma cells. J. Cell Sci. 2014, 127, 3735-3744. [CrossRef] [PubMed]

118. Guo, L.; Chen, H.; Li, Y.; Zhou, Q.; Sui, Y. An aquaporin 3-notch1 axis in keratinocyte differentiation and inflammation. PLoS ONE 2013, 8, 1-10. [CrossRef] [PubMed]

119. Lennicke, C.; Rahn, J.; Lichtenfels, R.; Wessjohann, L.A.; Seliger, B. Hydrogen peroxide-production, fate and role in redox signaling of tumor cells. Cell Commun. Signal. 2015, 13, 39. [CrossRef] [PubMed]

120. Direito, I.; Madeira, A.; Brito, M.A.; Soveral, G. Aquaporin-5: From structure to function and dysfunction in cancer. Cell. Mol. Life Sci. 2016, 73, 1623-1640. [CrossRef] [PubMed]

(C) 2017 by the authors. Licensee MDPI, Basel, Switzerland. This article is an open access article distributed under the terms and conditions of the Creative Commons Attribution (CC BY) license (http:/ / creativecommons.org/licenses/by/4.0/). 